\title{
Hepatitt E - en neglisjert sykdom i Norge
}

Globalt er hepatitt E et stort folkehelseproblem. Hvert år smittes minst 20 millioner mennesker, mer enn tre millioner blir syke (1) og rundt 50000 dør (2).

Eksistensen av et nytt virus med mange av de epidemiologiske og kliniske kjennetegnene til hepatitt A-virus ble først foreslått etter et vannbårent utbrudd i Kashmir-dalen i India i 1978 (3). Noen år senere demonstrerte den sovjetiske legen Mikhail S. Balayan at smitteveien var fekal-oral, ved selv å drikke et avføringsekstrakt fra syke soldater i en militærleir i Afghanistan. Etter en måneds tid fikk han magesmerter og oppkast, etterfulgt av feber og icterus, og i avføringen hans fant forskerteamet viruslignende partikler (4). I 1990 ble dette nye viruset klonet, sekvensert og gitt navnet hepatitt E-virus (5).

I dag vet vi at det finnes minst fire typer hepatitt E-virus. Genotype 1 og 2 infiserer bare mennesker og forårsaker epidemier og sporadiske tilfeller i utviklingsland, hovedsakelig via forurenset drikkevann. Sykdommen er med få unntak selvbegrensende og ufarlig hos ellers friske, men gravide har en rapportert dødelighet på 15-25\% i tredje trimester (6). Hos pasienter med kronisk leversykdom kan superinfeksjon med hepatitt E-virus føre til dekompensert leversvikt og død (7).

Hepatitt E-virus genotype 3 og 4 er zoonotiske virus. Disse gir sporadisk sykdom hos mennesker og kan forårsake utbrudd også $\mathrm{i}$ industrialiserte land. Smitte skjer sannsynligvis hovedsakelig gjennom animalske matvarer som er utilstrekkelig varmebehandlet, blant annet kjøtt fra gris, villsvin og hjort (8). Viruset kan også potensielt overføres ved blodtransfusjon (9). Infeksjon med genotype 3 er oftest asymptomatisk, men akutt hepatitt og ekstrahepatiske manifestasjoner forekommer. Kronisk hepatitt E er beskrevet hos pasienter med immunsvikt, spesielt gjelder det organtransplanterte (10).

Hepatitt E har inntil nylig vært oppfattet som en sjelden importsykdom i Norge (11). I de senere år har det imidlertid kommet rapporter fra mange europeiske land om høy seroprevalens og tilfeller av sykdom med genotype 3, blant annet fra Danmark og Sverige (12). I Norge er antistoff mot hepatitt $\mathrm{E}$ funnet hos $14 \%$ av norske blodgivere (13) og hos over $75 \%$ av testede griser (14). Fra kloakkanlegg ble hepatitt E-virus påvist i $8 \%$ av prøvene, hovedsakelig genotype 3, som ligner virus funnet hos gris (15). I dette nummer av Tidsskriftet rapporterer Alexander Løvdahl \& Joakim Øverbø det første tilfellet av akutt hepatitt E etter smitte i Norge (16). Mangelfull kunnskap om sykdommen gjør at det er svært sannsynlig at mange tilfeller får feil diagnose, for eksempel toksisk hepatitt.

Hepatitt E har vært lavt prioritert av norske helsemyndigheter, og vi vet for lite om forekomst og betydning i vårt land. Sykdommen overvåkes ikke av Meldingssystem for smittsomme sykdommer, og risikoen for overføring ved blodtransfusjon er ikke tilstrekkelig belyst. I Nasjonal strategi for arbeidet mot virale leverbetennelser (hepatitter) vies Hepatitt E liten oppmerksomhet - utover at det pekes på at Mattilsynet må bidra til å øke kunnskapen om matvarer som kan spre hepatitt E-smitte (17). Det er et viktig bidrag, men bærer ikke bud om noe krafttak for å øke kunnskap om sykdommens betydning i vårt land.

\section{Arne Broch Brantsæter}

arne.broch.brantsaeter@ous-hf.no

Arne Broch Brantsæter (f. 1959) er overlege ved Infeksjonsmedisinsk avdeling ved Oslo universitetssykehus og Nasjonal behandlingstjeneste for CBRNE-medisin.

Forfatter har fylt ut ICMJE-skjemaet og oppgir ingen interessekonflikter.

\section{Litteratur}

1. Rein DB, Stevens GA, Theaker J et al. The global burden of hepatitis E virus genotypes 1 and 2 in 2005. Hepatology 2012; 55: 988-97.

2. GBD 2013 Mortality and Causes of Death Collaborators. Global, regional, and national age-sex specific all-cause and cause-specific mortality for 240 causes of death, 1990-2013: a systematic analysis for the Global Burden of Disease Study 2013. Lancet 2015; 385: 117-71.

3. Khuroo MS. Study of an epidemic of non-A, non-B hepatitis. Possibility of another human hepatitis virus distinct from post-transfusion non-A, non-B type. Am J Med 1980; 68: 818-24.

4. Balayan MS, Andjaparidze AG, Savinskaya SS et al. Evidence for a virus in non-A, non-B hepatitis transmitted via the fecal-oral route. Intervirology 1983; 20 : 23-31.

5. Reyes GR, Purdy MA, Kim JP et al. Isolation of a cDNA from the virus responsible for enterically transmitted non-A, non-B hepatitis. Science 1990; 247 $1335-9$.

6. Khuroo MS, Teli MR, Skidmore S et al. Incidence and severity of viral hepatitis in pregnancy. Am J Med 1981; 70: 252-5.

7. Hamid SS, Atiq M, Shehzad F et al. Hepatitis E virus superinfection in patients with chronic liver disease. Hepatology 2002; 36: 474-8.

8. Guillois Y, Abravanel F, Miura T et al. High Proportion of Asymptomatic Infections in an Outbreak of Hepatitis E Associated With a Spit-Roasted Piglet, France, 2013. Clin Infect Dis 2016; 62: 351-7

9. Vollmer T, Diekmann J, Eberhardt M et al. Hepatitis E in blood donors: investigation of the natural course of asymptomatic infection, Germany, 2011. Euro Surveill 2016: 21: 30332

10. Kamar N, Selves J, Mansuy JM et al. Hepatitis E virus and chronic hepatitis in organ-transplant recipients. N Engl J Med 2008; 358: 811-7.

11. Sarvari SI, Hoddevik G, Brantsaeter AB. Akutt hepatitt E. Tidsskr Nor Lægeforen 2007: 127: 1966-8.

12. Norder H, Sundqvist L, Magnusson L et al. Endemic hepatitis E in two Nordic countries. Euro Surveill 2009; 14: 19211

13. Referansegruppen for ekstern kvalitetssikring i virologi og serologi. Strategimøte 2015. Laboratoriediagnostikk ved nye og utbruddsaktuelle virusinfeksjoner. Oslo: Nasjonalt folkehelseinstitutt, 2016. www.fhi.no/publ/strategimoter/ strategimote-2015/ (21.9.2016)

14. Veterinærinstituttets rapportserie 11-2014. Veterinærinstituttets faglige aktivitetsrapport 2013. Oslo: Veterinærinstituttet, 2014. http://vetinst.prod1.seeds.no/ Publikasjoner/Rapportserie/Rapportserie-2014/Veterinaerinstituttets-fagligeaktivitetsrapport-2013 (21.9.2016)

15. Myrmel M, Lange H, Rimstad E. A 1-Year Quantitative Survey of Noro-, AdenoHuman Boca-, and Hepatitis E Viruses in Raw and Secondarily Treated Sewage from Two Plants in Norway. Food Environ Virol 2015; 7: 213-23.

16. Løvdahl A, Øverbø J. En pasient i 20 -årene med icterus og smerter i ledd og muskler. Tidsskr Nor Legeforen 2016; 136: 1651-2.

17. Helse- og omsorgsdepartementet. Nasjonal strategi for arbeidet mot virale leverbetennelser (hepatitter). 2016. www.regjeringen.no/no/dokumenter/ nasjonal-strategi-for-arbeidet-mot-virale-leverbetennelser-hepatitter/ id2504728/ (21.9.2016). 